\title{
MANAJEMEN PEMERINTAHAN DALAM PROGRAM UNIT REAKSI CEPAT TAMBAL JALAN DI KOTA BANDUNG TAHUN 2015
}

\author{
Herry Suharyadi \\ Mohamad Aji Insani \\ Program Studi Ilmu Pemerintahan \\ Fakultas Ilmu Sosial dan Ilmu Politik Universitas Padjadjaran \\ e-mail:herry.suharyadi@gmail.com
}

\begin{abstract}
ABSTRAK
Tujuan dari penelitian ini adalah untuk mendeskripsikan bagaimana proses manajemen pemerintahan dilihat dari aspek perencanaan pemerintahan, pengorganisasian sumbersumber pemerintahan, penggunaan sumber-sumber pemerintahan, dan kontrol pemerintahan itu sendiri. Penelitian ini menggunakan metode deskriptif dengan pendekatan kualitatif. Teknik pengumpulan data yang digunakan adalah studi pustaka dan studi lapangan berupa observasi, wawancara dan dokumentasi. Penelitian ini dilakukan di instansi pemerintah terkait, yaitu Dinas Bina Marga dan Pengairan Kota Bandung. Berdasarkan hasil penelitian, program Unit Reaksi Cepat Tambal Jalan di Kota Bandung Tahun 2015 belum berjalan dengan optimal. Hal ini dikarenakan kurangnya sosialisasi antara pemerintah dengan masyarakat, komunikasi dan koordinasi belum berjalan dengan baik serta kurangnya sumberdaya - sumberdaya pemerintah sehingga program tersebut sempat terhenti di akhir tahun. Oleh karena itu disarankan perlu adanya perencanaan yang lebih matang, pengorganisasian jumlah pegawai yang mencukupi, memperbaiki komunikasi dan koordinasi dengan masyarakat, serta penggunaan dan penyediaan anggaran secara tepat.
\end{abstract}

Kata Kunci: Manajemen pemerintahan, Infrastruktur Jalan

\begin{abstract}
The purpose of this study was to describe how the process of government management from aspect of government planning, organizing government resources, the use of government resources, and control of the government itself. This research uses descriptive method with qualitative approach. Data collection techniques used are literature studies and field studies such as observation, interviews and documentation. This research was conducted in the relevant government agencies, DBMP city of Bandung. Based on this research, the program is not running optimally. This is due to lack of government and community socialization, communication and coordination have not been going well and the lack of resources - government resources so that the program had been halted at the end of the year. It is therefore suggested the need for a more mature planning, organizing a sufficient number of employees, improve communication and coordination with the public, as well as the use and allocation of budget appropriately.
\end{abstract}

Keywords: Government Management, Road Infrastructure 


\section{PENDAHULUAN}

Sarana dan prasarana fisik, atau sering disebut dengan infrastuktur, merupakan bagian yang sangat penting dalam sistem pelayanan masyarakat. Berbagai fasilitas fisik merupakan hal yang vital guna mendukung gerak roda pemerintahan, perekonomian, industri dan berbagai kegiatan sosial di masyarakat dan pemerintahan.

Dewasa ini, beratnya beban pendanaan bagi pembangunan baru maupun pemeliharaan fasilitas infrastruktur tidak dapat ditanggulangi oleh kemampuan pemerintah dalam mengimbangi kebutuhan akan infrastruktur yang semakin meningkat. Kondisi ini semakin diperparah dengan adanya kenyataan bahwa selama ini tampaknya kita terlena dengan pembangunan - pembangunan baru, sementara upaya memelihara fasilitas infrastruktur yang ada pun hampir tidak memperoleh perhatian yang memadai. Prasarana jalan merupakan salah satu fasilitas infrastruktur transportasi yang paling strategis, untuk mempertahankan kinerjanya, maka prasarana jalan perlu dikelola sedemikian rupa, sehingga kondisinya dapat terpelihara semaksimal mungkin dengan pendanaan yang optimum, tindakan pemeliharaan yang dilakukan secara berkala akan menjaga kualitas jalan dan memperpanjang usia layanannya.

Jalan rusak merupakan salah satu masalah yang ada di Kota Bandung. Kota Bandung memiliki panjang total jalan sepanjang
$1.232,48 \mathrm{~km}$. Total jalan tersebut dibagi pembinaannya dengan komposisi menjadi Jalan Nasional, Jalan Provinsi, dan Jalan Kota. Sepanjang 33,56 km merupakan jalan yang menjadi binaan dan tanggung jawab Pemerintah Negara Indonesia atau Jalan Nasional, sedangkan 17,54 km merupakan binaan dan tanggung jawab Pemerintah Provinsi Jawa Barat atau Jalan Provinsi, dan sepanjang $1.181,38 \mathrm{~km}$ merupakan binaan dan tanggung jawab Pemerintah Kota Bandung atau merupakan Jalan Kota.

Berdasarkan data yang didapat, pada tahun 2009 proporsi panjang jaringan jalan dalam kondisi baik mencapai $49,22 \%$ meningkat menjadi 68,96\% pada tahun 2013. Hal ini menunjukkan masih ada sekitar $33 \%$ atau 1/3 panjang jaringan jalan di Kota Bandung yang masih dalam kondisi rusak sedang atau berat. ${ }^{1}$ Total jumlah 33\% merupakan jumlah yang sangat besar bagi sebuah kota besar. Hal tersebut telah menguatkan fenomena bahwa masalah jalan rusak di Kota Bandung merupakan masalah yang cukup besar dan membutuhkan penyelesaian segera.

Sebagai salah satu solusi, pada tanggal 19 November 2013 Pemerintah Kota Bandung meluncurkan sebuah program dalam upaya pemeliharaan jalan di Kota Bandung yaitu dengan membuat

\footnotetext{
1 Rencana Strategis (Renstra) Dinas Bina Marga dan Pengairan Kota Bandung 20132018, hal. 9
} 
Pasukan Unit Reaksi Cepat Tambal Jalan. Program ini bertujuan untuk memperpanjang usia kelayakan jalan-jalan di Kota Bandung yang kegiatannya berupa pemeliharaan jalan dengan prioritas pada laporanlaporan yang diadukan oleh masyarakat mengenai jalan yang berlubang. Dengan adanya Program ini diharapkan permasalahan jalan berlubang yang ada di Kota Bandung sedikit demi sedikit dapat diselesaikan dan diminimalisir dampak negatifnya dan agar output yang dihasilkan berupa terpeliharanya jalan kota Bandung dengan baik.

Berdasarkan hasil wawancara dengan Kepala Bidang Pemeliharaan dan Kebinamargaan, Herdis Bekti menjelaskan bahwa dalam pelaksanaannya, program Unit Reaksi Cepat tambal jalan ini masih terdapat berbagai permasalahan lain, sehingga pelaksanaannya kurang begitu maksimal. Pertama mengenai aspek perencanaan bahwa program Unit Reaksi Cepat Tambal Jalan merupakan inovasi dari program pemeliharaan jalan, sehingga belum ada payung hukum yang jelas untuk mendukung program tersebut.

Dari aspek pengorganisasian belum jelasnya pembagian tugas dan wewenang tim yang dibentuk oleh Pemerintah Kota Bandung dan jumlah personil URC tambal jalan yang masih minim. Dari aspek penggerakan belum jelasnya bentuk komunikasi dan koordinasi antara Pemerintah dengan masyarakat, selain itu Pemerintah Kota Bandung hanya memiliki sumber daya dengan kuantitas terbatas sehingga menjadi penghambat dalam pelaksanaan program Unit Reaksi Cepat Tambal Jalan. Dari aspek pengawasan belum adanya standar pengawasan yang jelas untuk mengawasi bahwa program ini dilaksanakan dengan baik karena masih ditemukan ruasruas jalan yang sudah diperbaiki namun dengan cepat mudah rusak kembali, hal ini mengindikasikan bahwa umur jalan yang telah dilakukan penambalan jalan tidak selama yang telah direncakan sebelumnya, maka dari permasalahan yang terjadi terkait dengan pelaksanaan program Unit Reaksi Cepat tambal jalan dalam rangka memelihara infrastruktur jalan yang berlubang, maka diperlukan manajemen yang baik dimana harus dijalankan oleh Pemerintah Kota Bandung.

\section{TINJAUAN PUSTAKA}

\section{a. Manajemen}

Secara etimologi, manajemen berasal dari bahasa Inggris yaitu management yang berasal dari kata kerja to manage berarti kontrol. Dalam bahasa Indonesia manajemen dapat diartikan: mengendalikan, menangani, atau mengelola. Menurut Ndraha dalam bukunya Kybernology (Ilmu Pemerintahan Baru) I disebutkan bahwa istilah manajemen datang dari bahasa Inggris management. Istilah ini terbentuk dari akar kata manus, tangan, yang berkaitan dengan kata menagerie yang berarti beternak. Menagarie 
juga berarti sekumpulan binatang liar yang dikendalikan di dalam pagar. Kata manus berkaitan dengan kata manage yang berasal dari bahasa Latin mansionaticum yang berarti pengelolaan rumah besar. Manajemen mempelajari bagaimana menciptakan effectiveness usaha (doing right things) secara efficient (doing things right) dan produktif, melalui fungsi dan siklus tertentu, dalam rangka mencapai tujuan organisasional yang telah ditetapkan (Ndraha, 2011: 159).

Fungsi manajemen adalah elemen-elemen dasar yang akan selalu ada dan melekat di dalam proses manajemen yang akan dijadikan acuan oleh manajer dalam melaksanakan kegiatan untuk mencapai tujuan.

Menurut G.R. Terry dalam bukunya Prinsip-Prinsip Manajemen mengenai fungsi-fungsi manajemen :

1. Fungsi Perencanaan (Planning)

Planning ialah menetapkan pekerjaan yang harus dilaksanakan oleh kelompok untuk mencapai tujuan yang digariskan, planning mencakup kegiatan pengambilan keputusan, karena termasuk pemilihan alternatif-alternatif keputusan.

2. Fungsi Pengorganisasian (Organizing)

Organizing mencakup : (a) membagi komponenkomponen kegiatan yang dibutuhkan untuk mencapai tujuan ke dalam kelompok-kelompok, membagi tugas kepada seorang manajer untuk mengadakan

pengelompokan tersebut dan (c) menetapkan wewenang di antara kelompok atau unit-unit organisasi.

3. Fungsi Penggerakan (Actuating)

Actuating mencakup kegiatan yang dilakukan oleh seorang manager untuk mengawali dan melanjutkan kegiatan yang ditetapkan oleh unsur perencanaan dan pengorganisasian agar tujuan-tujuan dapat tercapai.

4. Fungsi Pengawasan (Controlling)

Controlling mencakup kelanjutan tugas untuk melihat apakah kegiatankegiatan dilaksanakan sesuai rencana. Pelaksanaan kegiatan dievaluasi dan penyimpangan-

penyimpangan yang tidak diinginkan diperbaiki supaya tujuan-tujuan dapat tercapai dengan baik.

(Terry, 2013: 17-18)

\section{b. Pemerintah}

Sebagai makhluk sosial, manusia membutuhkan manusia lain 
untuk bekerja sama dalam memenuhi segala kebutuhan hidupnya, termasuk keamanan, kenyamanan, keselamatan, dan kesejahteraan. Dalam bekerja sama inilah manusia membutuhkan suatu wadah tertentu tempat manusia bekerja sama. Manusia bersatu dalam suatu tatanan bermasyarakat yang biasa dikenal dengan istilah "Negara".

Berkaitan dengan hal tersebut dalam menjalankan Negara, Salam mengemukakan :

"Untuk menjalankan sebuah negara agar dapat mencapai ketentraman, kesejahteraan, dan kesentosaan bersama diperlukan penguasa yang mengatur dan mengelola segenap sumber daya untuk mencapai tujuan suatu negara. Penguasa dalam terminologi ilmu negara, ilmu politik, ilmu administrasi biasanya dengan istilah pemerintah. Sedangkan kegiatan pemerintah dalam menjalankan kekuasaan negara disebut dengan istilah pemerintahan." (Salam, 2007: 34)

Kemudian tidak jauh berbeda dengan makna dari pengertian pemerintah di atas, Salam mendefinisikan pemerintah sebagai berikut:

"Pada dasarnya pemerintah adalah sekelompok orang yang diberi kekuasaan legal oleh masyarakat setempat untuk melaksanakan pengaturan atas interaksi yang terjadi dalam pergaulan masyarakat untuk memenuhi kebutuhan dan keperluan hidup sehari-hari, sehingga interaksi tersebut dapat berjalan secara harmonis." (Salam, 2007: 34)

Sedangkan menurut Taliziduhu Ndraha, pengertian pemerintah adalah :

"Organ yang berwenang memproses pelayanan publik dan berkewajiban memproses pelayanan civil bagi setiap orang melalui hubungan pemerintahan pada saat yang diperlukan, sesuai dengan tuntutan (harapan) yang diperinta. Dalam hubungan itu bahkan warga negara asing atau siapa saja yang pada suatu saat berada secara sah (legal) di wilayah indonesia, berhak menerima layanan civil tertentu dan pemerintah wajib melayankannya." (Ndraha, 2011: 6)

\section{c. Manajemen Pemerintahan}

Dari penjelasan mengenai pengertian manajemen dan pemerintahan, kita kemudian kita mengenal istilah manajemen pemerintahan.

Istianto dalam bukunya Manajemen Pemerintahan dalam Perspektif Pelayanan Publik mengatakan bahwa "Manajemen pemerintahan diartikan pada bagaimana 
secara organisasional untuk mengimplementasikan

kebijakan publik. Dengan demikian manajemen pemerintahan lebih terfokus pada alat-alat manajerial, teknis pengetahuan dan keterampilan yang dapat digunakan untuk mengubah ide-ide dan kebijakan menjadi program tindakan". (Istianto, 2011: 29)

Dari beberapa penjelasan di atas, dapat dilihat bahwa di dalam manajemen pemerintahan juga menyoroti proses perencanaan, pengorganisasian, pelaksanaan, dan pengawasan yang dilakukan oleh pemerintah dalam rangka memberikan pelayanan kepada masyarakat.

Penyelenggaraan pemerintahan Indonesia di dalam kerangka negara kesatuan, antara pemerintah pusat dan pemerintah daerah di dalam pelaksanaannya tidak dapat dilepaskan dari penggunaan asas penyelenggaraan pemerintahan di daerah. UU No.23 Tahun 2014 tentang Pemerintahan Daerah yang pada prinsipnya mengatur penyelenggaraan pemerintahan daerah yang lebih mengutamakan pelaksanaan asas desentralisasi.

Konsep dasar dari manajemen pemerintahan tidak lain adalah manajemen itu sendiri. Manajemen pada intinya menurut Ndraha adalah "bagaimana menciptakan effectiveness usaha ("doing right things") secara efficient ("doing things right") dan produktif, melalui fungsi dan skill tertentu, dalam rangka mencapai tujuan organisasional yang telah ditetapkan." (Ndraha, 2011: 159).

Fungsi-fungsi manajemen pemerintahan yang dimaksud Taliziduhu Ndraha dalam bukunya yang berjudul Kybernology (Ilmu Pemerintahan Baru) Jilid 1 (Ndraha, 2011: 160), antara lain :

1. Perencanaan pemerintahan; dilakukan untuk mengklarifikasi tujuan organisasi dan menyusun langkah-langkah guna mencapai tujuan (tujuan konkret dan terukur) organisasi.

2. Pengorganisasian sumbersumber pemerintahan; realisasi (implementasi) langkah-langkah tersebut memerlukan sumber daya, baik SDA, SDM, maupun SDB. Sebelum digunakan, sumber daya harus diorganisasikan agar siap pakai.

3. Penggunaan sumber-sumber pemerintahan; dilakukan untuk menggerakkan sumber-sumber pemerintahan agar mendapatkan hasil-hasil yang sudah ditetapkan.

4. Kontrol pemerintahan; dilakukan untuk menjamin kesesuaian antara target pada perencanaan dengan hasil yang diperoleh dari penggunaan sumber-sumber pemerintahan tersebut

\section{METODE PENELITIAN}

Dalam penelitian ini penulis menggunakan metode deskriptif, menurut Nazir, yang dimaksud dengan: 
"Metode deskriptif adalah suatu metode dalam meneliti status kelompok manusia, suatu objek, suatu kondisi, sistem pemikiran atau kelas peristiwa pada masa sekarang. Tujuan dari penelitian deskriptif adalah untuk membuat deskripsi, gambaran atau lukisan secara sistematis, faktual dan akurat mengenai suatu fakta, sifat dan fenomena yang diselidiki”. (Nazir, 2003: 54)

Dengan menggunakan metode deskriptif ini penulis akan memberi gambaran secara jelas dan sistematis mengenai fakta-fakta dilapangan. Melalui penyelidikan suatu kondisi, mengumpulkan data yang ada, mengklarifikasikan selanjutnya menganalisis masalah dengan menghubungkan teori yang ada guna memecahkan suatu masalah secara tepat. Selain itu penulis juga dapat menggambarkan secara jelas bagaimana Manajemen Pemerintah Kota Bandung dalam upaya memelihara jalan yang berlubang melalui Program Unit Reaksi Cepat Tambal Jalan dilihat dari aspek perencanaannya, pengorganisasian, penggerakan sampai dengan pengawasannya.

Pendekatan yang digunakan dalam penelitian ini adalah pendekatan kualitatif. Sugiyono mengemukakan bahwa:

"Dalam penelitian kualitatif pengumpulan data tidak dipandu oleh teori, tetapi dipandu oleh fakta-fakta yang ditemukan pada saat penelitian di lapangan. Oleh karena itu analisis data yang dilakukan bersifat induktif berdasarkan fakta-fakta yang ditemukan dan kemudian dapat dikonstruksikan menjadi hipotesis atau teori." (Sugiyono, 2014: 3)

Lebih lanjut Creswell mengemukakan karakteristik penelitian kualitatif dilihat dari segi tahapan penelitian sebagai berikut :

“(1) Mengeksplorasi suatu masalah dan mengembangkan sebuah pemahaman yang detail tentang sebuah tema utama. (2) Memiliki tinjauan literatur yang memainkan peranan kecil, tetapi menjustifikasi masalah. (3) Menentukan tujuan dan pertanyaan-pertanyaan penelitian dalam cara yang umum dan luas mengenai pengalaman-pengalaman

partisipan.

Mengumpulkan berdasarkan pada kata-kata dari sejumlah kecil individu sehingga pandangan partisipan diperoleh. (5) Menganalisis data untuk deskripsi dan tema-tema dengan menggunakan analisis teks dan menginterprestasi makna yang lebih besar tentang temuan-temuan. (6) Menulis laporan dengan menggunakan struktur-struktur yang darurat dan fleksibel dan 
mengevaluasi kriteria,dan termasuk efektivitas subjektif dan bias." (Ahmadi, 2014: 18)

Teknik pengumpulan data merupakan langkah yang paling strategis dalam penelitian, karena tujuan utama dari penelitian adalah mendapatkan data. Tanpa mengetahui teknik pengumpulan data, maka peneliti tidak akan mendapatkan data yang memenuhi standar data yang ditetapkan. Guna memperoleh keterangan dan faktafakta selengkap mungkin dari keadaan empirik dalam penelitian ini maka penulis menggunakan beberapa teknik pengumpulan data. Menurut Sugiyono, ada beberapa macam teknik pengumpulan data dalam penelitian, yaitu Observasi (pengamatan), interview (wawancara), dokumentasi, dan gabungan/triangulasi (Sugiyono, 2014: 63). Senada dengan pendapat Sugiyono tersebut maka dalam penelitian ini penulis menggunakan teknik pengumpulan data tersebut.

Adapun informan dan informasi yang diperlukan antara lain:

1. Kepala Dinas Bina Marga dan Pengairan Kota Bandung

Untuk mengetahui bagaimana perencanaan, pengorganisasian, dan pengawasan dalam program Unit Reaksi Cepat tambal jalan di Kota Bandung pada tahun 2015

2. Kepala Bidang Pemeliharaan Jalan

Untuk mengetahui bagaimana perencanaan, pengorganisasian, penggerakan dan pengawasan dalam program Unit Reaksi Cepat tambal jalan di Kota Bandung pada tahun 2015

3. Staff/Admin twitter @ dbmpkotabdg dan whatsapp DBMP PUPUHU

Untuk mengetahui bagaimana perencanaan, penggerakan dan pengawasan dalam program Unit Reaksi Cepat tambal jalan di Kota Bandung pada tahun 2015

4. Kepala Unit Pelaksana Teknis (UPT) 6 wilayah

Untuk mengetahui bagaimana pengorganisasian, penggerakan dan pengawasan dalam program Unit Reaksi Cepat tambal jalan di Kota Bandung pada tahun 2015

5. Masyarakat pengguna twitter @ dbmpkotabdg

Tolak ukur keberhasilan program Unit Reaksi Cepat tambal jalan di Kota Bandung pada tahun 2015

Teknik analisis data yang dipakai dalam penelitian ini adalah Model Miles and Huberman. Sugiyono berpendapat :

"Teknik analisis model Miles and Huberman ini, analisis data yang dilakukan pada saat pengumpulan data berlangsung dan setelah selesai pengumpulan data dalam periode tertentu. Aktivitas dalam analisis data yaitu data reduction, data display, dan conclusion drawing/verification."

(Sugiyono, 2014: 91)

HASIL DAN PEMBAHASAN 
Penyajian pembahasan hasil penelitian mengenai hal tersebut, akan penulis sajikan berdasarkan identifikasi masalah yang terdiri dari empat bagian yaitu manajemen pemerintahan dalam program pemeliharaan jalan melalui Unit Reaksi Cepat di Kota Bandung tahun 2015 berdasarkan perencanaan, pengorganisasian, penggerakkan dan pengawasannya.

\section{a. Perencanaan Pemerintahan dalam program pemeliharaan jalan melalui Unit Reaksi Cepat di Kota Bandung tahun 2015}

Awal mula dikeluarkannya sebuah perencanaan kebijakan dalam rangka meningkatkan kapasitas dan kualitas jaringan jalan melalui program Unit Reaksi Cepat Tambal Jalan di Kota Bandung tahun 2015, dilatarbelakangi oleh banyaknya jaringan jalan dengan kondisi rusak hampir di seluruh wilayah Kota Bandung karena keselamatan orang dan barang dalam penyelenggaraan layanan jalan juga harus menjadi perhatian. Oleh karena itu layanan jalan dalam kondisi mantap menjadi sebuah kebutuhan, ditambah dengan amanat UU no. 22 Tahun 2009 yaitu, "Penyelenggara jalan wajib segera dan patut untuk memperbaiki jalan yang rusak yang dapat mengakibatkan kecelakaan lalu lintas", menjadi acuan bahwa kondisi jalan harus dapat melewatkan pergerakan orang dan barang dengan baik. $^{2}$

${ }^{2}$ Hasil wawancara peneliti dengan Kepala DBMP Kota Bandung, tanggal 04 Juni 2015
Selain itu kebijakan dalam rangka meningkatkan kapasitas dan kualitas jaringan jalan melalui program Unit Reaksi Cepat Tambal Jalan di Kota Bandung tahun 2015 oleh Pemerintah Kota Bandung ini dilatarbelakangi pula oleh kondisi fisik wilayah kota Bandung sebagai daerah cekungan dengan kandungan air tanah tinggi yang dapat mempercepat kerusakan fisik jalan. Ketika musim penghujan potensi kerusakan jalan di Bandung jauh lebih besar pada saat kondisi basah dibandingkan pada kondisi kering. Hal ini disebabkan air sering tidak tertampung dan menggenangi banyak segmen jalan, baik saluran pinggir jalan maupun saluran-saluran pembuangan lainnya.

Berdasarkan permasalahan tersebut, maka Pemerintah Kota Bandung membuat sebuah perencanaan program atau kebijakan sebagai dalam rangka meningkatkan kapasitas dan kualitas jaringan jalan. Pada tahun 2013, Walikota Bandung Ridwan Kamil mencanangkan sebuah program yang bernama "Unit Reaksi Cepat Tambal Jalan" yang merupakan inovasi dari program pemeliharaan jalan, adanya unit ini membuat masyarakat Kota Bandung dapat ikut berpatisipasi dengan melakukan pelaporan jalan yang rusak di wilayah kota bandung.

$$
\text { Berdasarkan data yang }
$$
peneliti dapatkan, program pemeliharaan jalan sudah diluncurkan pada tahun 2005 sejak masa kepemimpinan Dada Rosada. Program ini mengacu pada Peraturan 
Daerah Kota Bandung Nomor 09

Tahun 2009 tentang Rencana

Pembangunan Jangka Menengah

Daerah (RPJMD) tahun 2009-2013

namun kurang berjalan optimal

karena dasar aturan program

pemeliharaan jalan terlambat

dikeluarkan dan tidak ada

transparansi serta keterlibatan

masyarakat.. Pada tahun 2013 di

masa kepemimpinan Ridwan Kamil

dibentuklah Program Unit Reaksi

Cepat Tambal Jalan yang merupakan inovasi dari Program Pemeliharaan Jalan. Dasar aturan yang menjadi pedoman dalam mengimplementasikan program tersebut dirilis pada tahun 2014 melalui Peraturan Daerah Kota Bandung Nomor 03 Tahun 2014 tentang Rencana Pembangunan Jangka Menengah Daerah (RPJMD) tahun 2014-2018.

Dalam Bab V RPJMD tersebut dijabarkan mengenai janji walikota dan wakil walikota terpilih dalam agenda "Bandung Resik". Yang dimaksud dengan "Bandung Resik" yaitu suatu keadaan yang menggambarkan bebas sampah dalam 2 tahun, bebas banjir dalam 3 tahun, jalan mulus dan caang ${ }^{3}$ dalam 3 tahun, dan bebas macet dalam 4 tahun.

Untuk mewujudkan Bandung Resik, pemerintah Kota Bandung dalam RPJMD Kota Bandung tahun 2014-2018 tersebut telah menetapkan 6 urusan program pekerjaan umum yaitu :

3 “caang” berasal dari bahasa sunda yang artinya terang
1. Program Pembangunan Jalan dan Jembatan

2. Program Pemeliharaan Jalan

3. Program Pembangunan Saluran Drainase/Goronggorong

4. Program Pemeliharaan Saluran

5. Program Pengendalian Banjir

6. Program Pengembangan, Pengelolaan, dan Konservasi Sungai, Danau, dan Sumber Daya Air Lainnya.

Selain RPJMD Kota Bandung sebagai landasan aturan program pemeliharaan jalan, ada pula dasar aturan bagi pelaksanaan program pemeliharaan jalan adalah UU no. 22 Tahun 2009 tentang Lalu Lintas dan Angkutan Jalan.

Dari data hasil temuan di lapangan tersebut, peneliti memandang Pemerintah Kota Bandung pada masa kepemimpinan Dada Rosada lamban dalam mengeluarkan dasar aturan yang menjadi pedoman dalam melakukan program pemeliharaan jalan, sehingga pelaksanaannya kurang berjalan optimal. Namun pada masa pemerintahan Ridwan Kamil, program pemeliharaan jalan melalui Unit Reaksi Cepat Tambal Jalan yang telah diluncurkan sejak tahun 2013, dasar aturannya diresmikan pada tahun 2014 sehingga proses program pemeliharaan jalan dapat berjalan dengan baik. 


\begin{abstract}
Berdasarkan temuan di lapangan, peneliti menginterpretasikan bahwa sasaran dari program Unit Reaksi Cepat Tambal Jalan ini yaitu untuk memenuhi infrastruktur jalan yang berkualitas dan merata. Sasaran tersebut harus mencapai $100 \%$ dalam jangka waktu 3 (tiga) tahun yakni di tahun 2016 maka dari itu dilakukan berbagai cara khususnya melalui pemeliharaan jalan. Hal ini karena komitmen dan konsen penuh dari walikota Bandung akan pentingnya jalan mulus bagi masyarakat Kota Bandung, sehingga mampu melayani pergerakan perkotaan dalam tingkat pelayanan yang baik menjadi nilai tambah untuk datangnya para wisatawan dan investasi.
\end{abstract}

Adapun maksud dan tujuan dari Program Unit Reaksi Cepat Tambal Jalan ini yaitu :

1. Mempertahankan kinerja jalan tetap dalam kondisi baik ;

2. Meminimalisirkan

kecelakaan

yang

diakibatkan

oleh

kerusakan jalan ;

3. Menunjang pertumbuhan ekonomi perkotaan

(Sumber : Dinas Bina Marga dan Pengairan Kota

Bandung)

Dalam meningkatkan

kapasitas dan kualitas jaringan jalan ini, direncanakanlah 2 (dua) strategi utama oleh Pemerintah Kota Bandung agar sasaran dapat dicapai yaitu guna mewujudkan infrastruktur jalan yang berkualitas dan merata di Kota Bandung.

Strategi pertama yang dilakukan oleh Pemerintah Kota Bandung dalam perencanaanya adalah dengan cara pemeliharaan terprogram. Yang dimaksud pemeliharaan terprogram adalah kegiatan yang sudah direncanakan sebelumnya dengan lokasi yang sudah ditentukan pula, lalu jenisjenis pekerjaan yang akan dilaksanakan berdasarkan plafon biaya yang disetujui, pembuatan jadwal pelaksanaan, jadwal pengoperasian peralatan, jadwal pengadaan bahan, tenaga kerja serta monitoring, evaluasi maupun revisi program bila diperlukan, team melakukan survey di wilayahnya dan memetakan lokasi jalan yang rusak sehingga team beserta alat beratnya dapat melakukan perbaikan jalan dengan mengikuti alur lokasi yang sudah ditentukan, hal ini dilakukan agar alat berat tidak kembali lagi ke UPT. $^{4}$

Strategi kedua yang akan dilakukan Pemerintah Kota Bandung berdasarkan perencanaannya yaitu melalui pemeliharaan jalan insidential/non program atau Unit Reaksi Cepat Tambal Jalan. Maksudnya adalah kegiatan pemeliharaan jalan skala kecil yang dilakukan secara tanggap darurat atas laporan dari masyarakat melalui sms, telepon, dan twitter @dbmpkotabdg, dalam hal ini Dinas Bina Marga dan Pengairan Kota Bandung akan selalu

${ }^{4}$ Ibid 
$\begin{array}{lrr}\text { memantau akun } & \text { twitter } \\ @ \text { dbmpkotabdg } & \text { untuk }\end{array}$ mengantisipasi dan merespon apabila ada laporan-laporan dari masyarakat. Jadi, dalam program Unit Reaksi Cepat Tambal Jalan di Kota Bandung, masyarakat dapat menggunakan jasa Unit Reaksi Cepat Tambal Jalan ini dengan menyampaikan keluhannya melalui SMS, telepon, atau twitter Dinas Bina Marga dan Pengairan Kota Bandung. Unit Reaksi Cepat Tambal Jalan ini akan merespon secara cepat keluhan warga mengenai jalan berlubang di Kota Bandung. Melalui tim URC ini perbaikan jalan dapat dilakukan dengan cepat, bahkan jika kerusakan jalan tidak begitu parah, Tim URC bisa mengerjakan kurang dari 24 jam. ${ }^{5}$

Dalam rangka meningkatkan kapasitas dan kualitas jaringan jalan melalui pemeliharaan jalan, Pemerintah Kota Bandung berupaya melibatkan peran masyarakat dalam program Unit Reaksi Cepat Tambal Jalan di Kota Bandung Tahun 2014. Masyarakat sebagai pengguna layanan jalan dapat melakukan penyampaian informasi melalui media sosial twitter yang sudah disediakan oleh Pemerintah Kota Bandung. Namun dalam hal ini peneliti menganggap pemerintah kurang begitu serius karena pemanfaatan media sosial ini tidak disebarkan melalui baliho, space iklan, ataupun iklan layanan masyarakat sehingga masih banyak

${ }^{5}$ Ibid masyarakat yang tidak mengetahui pemanfaatan media sosial twitter (@dbmpkotabdg).

Setelah adanya strategistrategi sebagai upaya untuk mencapai tujuan dan sasaran yang telah ditetapkan, maka berdasarkan teori dalam mengukur perencanaan, harus ada penetapan waktu dan prosedur kerja sebagai penegasan dari sistem pekerjaan yang akan dilakukan oleh Pemerintah Kota Bandung.

Berdasarkan data yang peneliti peroleh dari para informan melalui wawancara, penetapan waktu dan prosedur kerja yang ditempuh oleh Pemerintah Kota Bandung berdasarkan perencanaannya yaitu terbagi atas beberapa tahap, yaitu :

1. September 2013, Walikota Ridwan Kamil mencanangkan Jalan Mulus tahun 2016 dan membentuk Tim Unit Reaksi Cepat (URC) dengan memfasilitasi keperluan peralatannya.

2. Oktober 2013, pemanfaatan media sosial melalui internet mulai disebarluaskan dan Dinas Bina Marga dan Pengairan Kota Bandung membentuk akun sosial untuk memfasilitasi laporan dan aspirasi masyarakat, yaitu twiteer@dbmpkotabdg dan whaatsapp DBMP PUPUHU.

3. Maret 2014, melalui anggaran APBD Propinsi Jawa Barat diperoleh kendaraan modifikasi untuk operasional Tim URC 
Tambal Jalan sebesar $\mathrm{Rp}$

5.000.000.000,- serta pengadaan bahan material tambal jalan sebesar $\mathrm{Rp}$ 5.000.000.000,-.

4. Sampai dengan Desember 2015 Tim URC Tambal Jalan telah merespon hampir semua laporan dan aspirasi masyarakat dengan baik dan mendapati sambutan serta apresiasi positif dari masyarakat, bahkan menjadi favorit masyarakat Kota Bandung. ${ }^{6}$

\section{b. Pengorganisasian Sumber-} sumber Pemerintahan dalam program Unit Reaksi Cepat Tambal Jalan di Kota Bandung Tahun 2015

Pengorganisasian adalah suatu proses penentuan, pengelompokan, dan penaturan bermacam-macam aktivitas yang diperlukan untuk mencapai tujuan, menempatkan orang-orang pada setiap aktivitas ini, menyediakan alat-alat yang diperlukan, menetapkan wewenang yang secara relatif didelegasikan kepada setiap individu yang akan melakukan aktivitas-aktivitas tersebut.

Selain itu dalam fungsi ini juga berkaitan dengan penyuluhan wewenang yang dilimpahkan terhadap setiap orang yang berhubungan dengan pelaksanaan setiap kegiatan yang diharapkan.

${ }^{6}$ Ibid
Team dalam program Unit Reaksi Cepat Tambal Jalan, diisi oleh Satuan Kerja Perangkat Daerah (SKPD) Pemerintah Kota bandung yang memiliki tupoksi secara langsung berhubungan dengan pekerjaan umum yakni Dinas Bina Marga dan Pengairan Kota Bandung.

Struktur team program pemeliharaan jalan melalui Unit Reaksi Cepat Tambal Jalan yang telah disusun oleh Walikota Bandung selaku pimpinan, diisi oleh struktur inti teknis pelaksana program pemeliharaan jalan yaitu Kepala Dinas Bina Marga dan Pengairan Kota Bandung sebagai pimpinan SKPD. Kemudian selaku koordinator program pemeliharaan jalan, diisi oleh Kepala Bidang Seksi Pemeliharan Jalan. Lalu sebagai pelaksana teknis program pemeliharaaan jalan yaitu Unit Pelaksana Teknis (UPT) yang berada di 6 wilayah. ${ }^{7}$

Berdasarkan hasil penelitian dilapangan, diperoleh data bahwa Dinas Bina Marga dan Pengairan Kota Bandung dalam melaksanakan program pemeliharaan jalan telah membentuk struktur wewenang formal yakni Unit Pelaksana Teknis (UPT) ke dalam 6 wilayah. Hal ini dilakukan untuk mengefektifkan rentang kendali yang sangat besar. Pembentukan Unit Pelaksana Teknis (UPT) dalam program pemeliharaan jalan berdasarkan Peraturan Walikota Bandung No. 413 tahun 2010. Satuan kerja kebinamargaan dalam bentuk

${ }^{7}$ Hasil wawancara peneliti dengan Kepala 
Unit Pelaksana Teknis (UPT) wilayah di Dinas Bina Marga dan Pengairan, meliputi:

1) UPT Wilayah Ujungberung;

2) UPT Wilayah Gedebage;

3) UPT Wilayah Cibeunying;

4) UPT Wilayah Karees;

5) UPT Wilayah Bojonegara; dan

6) UPT Wilayah Tegallega.

Dari pemaparan peneliti diatas, saat ini team inti program Unit Reaksi Cepat Tambal Jalan yang menjalankan program sesuai dengan pembentukannya oleh Walikota Bandung selaku pimpinan, diisi oleh Kepala Dinas Bina Marga dan Pengairan Kota Bandung selaku Pimpinan SKPD, diisi oleh Kepala Bidang Pemeliharaan Jalan selaku Koordinator program Unit Reaksi Cepat Tambal Jalan. Koordinator team program pemeliharaan jalan ini membawahi 6 Kepala Unit Pelaksana Teknis yang terdiri dari 6 Wilayah UPT yang tersebar di Kota Bandung sebagai pelaksana teknis program Unit Reaksi Cepat Tambal Jalan.

Dalam Program Pemeliharaan Jalan melalui Unit Reaksi Cepat Tambal Jalan di Kota Bandung, setiap UPT wilayah memiliki 1 (satu) tim URC Tambal Jalan yang beranggotakan 10 orang. Tim URC direkrut berdasarkan kontrak/swakelola dari masyarakat yang memiliki keahlian dalam menangani infrastruktur jalan. ${ }^{8}$

Berdasarkan hasil data yang peneliti dapatkan bahwa dalam tim Unit Reaksi Cepat Tambal Jalan,

${ }^{8}$ Hasil wawancara peneliti dengan Kepala UPT Gedebage, tanggal 08 Mei 2015 kuantitas jumlah pegawainya masih kurang, karena sampai saat ini tiap UPT mempunyai kewenangan untuk merekrut pegawai secara swakelola hanya berjumlah 10 orang atau berarti satu tim. Sedangkan idealnya dalam setiap UPT memiliki 2 tim URC karena masing-masing tiap UPT memegang wilayah kerjanya sampai 6 kelurahan. Hal ini difungsikan agar program Unit Reaksi Cepat Tambal Jalan dapat melaksanakan pelayanan secara optimal dan semua keluhan dari masyarakat dapat di respon secara cepat. Setiap UPT di wilayah kerjanya diberikan beban tugas berdasarkan tupoksi dan ranah pekerjaannya dalam program pemeliharaan jalan. Maka untuk menunjang kinerja dan tuntutan tugas setiap UPT ini, para Kepala UPT selaku anggota team inti dalam program Unit Reaksi Cepat Tambal Jalan diberikan kewenangan untuk menunjuk orang-orang dari staff UPT-nya untuk turut bekerja menyelesaikan target yang dibebankan kepada setiap UPT tersebut. Sehingga dengan demikian, seluruh staff pada UPT-UPT dalam team program pemeliharaan jalan, turut berperan serta dalam melaksanakan Program pemeliharaan jalan dengan mendasar pada tugas dan tupoksi dari Dinas Bina Marga dan Pengairan Kota Bandung. ${ }^{9}$

Dalam struktur team Program pemeliharaan jalan yang terdiri dari SKPD-SKPD yang terlibat,

\footnotetext{
${ }^{9}$ Hasil wawancara peneliti dengan 6 Kepala UPT Pemeliharaan Jalan, Bulan Mei 2015
} 
dikoordinasikan oleh Kepala Bidang Pemeliharaan Dinas Bina Marga dan Pengairan Kota Bandung sebagai koordinator team Program pemeliharaan jalan seperti yang telah dijelaskan sebelumnya. Seperti yang diutarakan oleh Bapak Herdis Bekti, Koordinasi antar UPT dipimpin oleh Kepala Bidang Pemeliharaan DBMP sebagai koordinator team program pemeliharaan jalan dengan pemantauan dari Kepala Dinas Bina Marga dan Pengairan dan Walikota Bandung. ${ }^{10}$

Dengan demikian dapat dilihat, para anggota team yang menjalankan tugas-tugasnya, baik tugas dinasnya sendiri maupun tugas bersama dengan SKPD lainnya di koordinasikan secara langsung oleh koordinator team program pemeliharaan jalan yaitu Kepala Bidang Pemeliharaan Dinas Bina Marga dan Pengairan Kota Bandung.

Sumberdaya yang menjadi sarana dan prasarana dalam pelaksanaan pemeliharaan jalan melalui program Unit Reaksi Cepat Tambal Jalan di Kota Bandung peneliti memperoleh informasi mengenai anggaran yang berasal dari keuangan daerah sendiri yaitu APBD Kota Bandung dan Bantuan Provinsi untuk melaksanakan program pemeliharaan jalan di Tahun 2014. Pada tahun 2014 program Unit Reaksi Cepat Tambal Jalan mendapatkan bantuan dari provinsi berupa bahan-bahan material dan 1

${ }^{10}$ Ibid kendaraan truck di setiap UPT untuk perbaikan jalan.

\section{c. Penggunaan Sumber-sumber Pemerintahan dalam Program Unit Reaksi Cepat Tambal Jalan di Kota Bandung Tahun 2015}

Berdasarkan wawancara dengan Bapak Eka selaku operator dalam program Unit Reaksi Cepat Tambal Jalan, menjelaskan bahwa bentuk koordinasi yang dilakukan dalam pelaksanaan pemeliharaan jalan melalui Unit Reaksi Cepat Tambal Jalan bermula dari masyarakat sebagai pengguna jalan melaporkan kondisi jalan yang rusak secara deskriptif ataupun fotografik melalui akun twitter@dbmpkotabdg. Laporan tersebut diterima oleh operator Dinas Bina Marga dan Pengairan Kota Bandung dan segera di koordinasikan kepada pelaksana program URC Tambal Jalan di Dinas Bina Marga dan Pengairan Kota Bandung yang tergabung dalam whatsapp PUPUHU. Selanjutnya akan ada Unit Pelaksana Teknis yang menangani pemeliharaan jalan segera memerintahkan tim URC untuk menambal jalan pada lokasi yang telah dilaporkan warga Kota Bandung. Apabila perbaikan jalan sudah dilaksanakan, UPT operasional pemeliharaan jalan wilayah tersebut segera melaporkan hasil perbaikan jalan secara deskriptif dan fotografik kepada whatsapp PUPUHU agar dapat diketahui oleh seluruh pelaksana program URC Tambal Jalan. Selanjutnya operator 
melaporkan kembali jalan yang sudah diperbaiki kepada warga Kota Bandung melalui akun twitter Dinas Bina Marga dan Pengairan Kota Bandung (@dbmpkotabdg). ${ }^{11}$

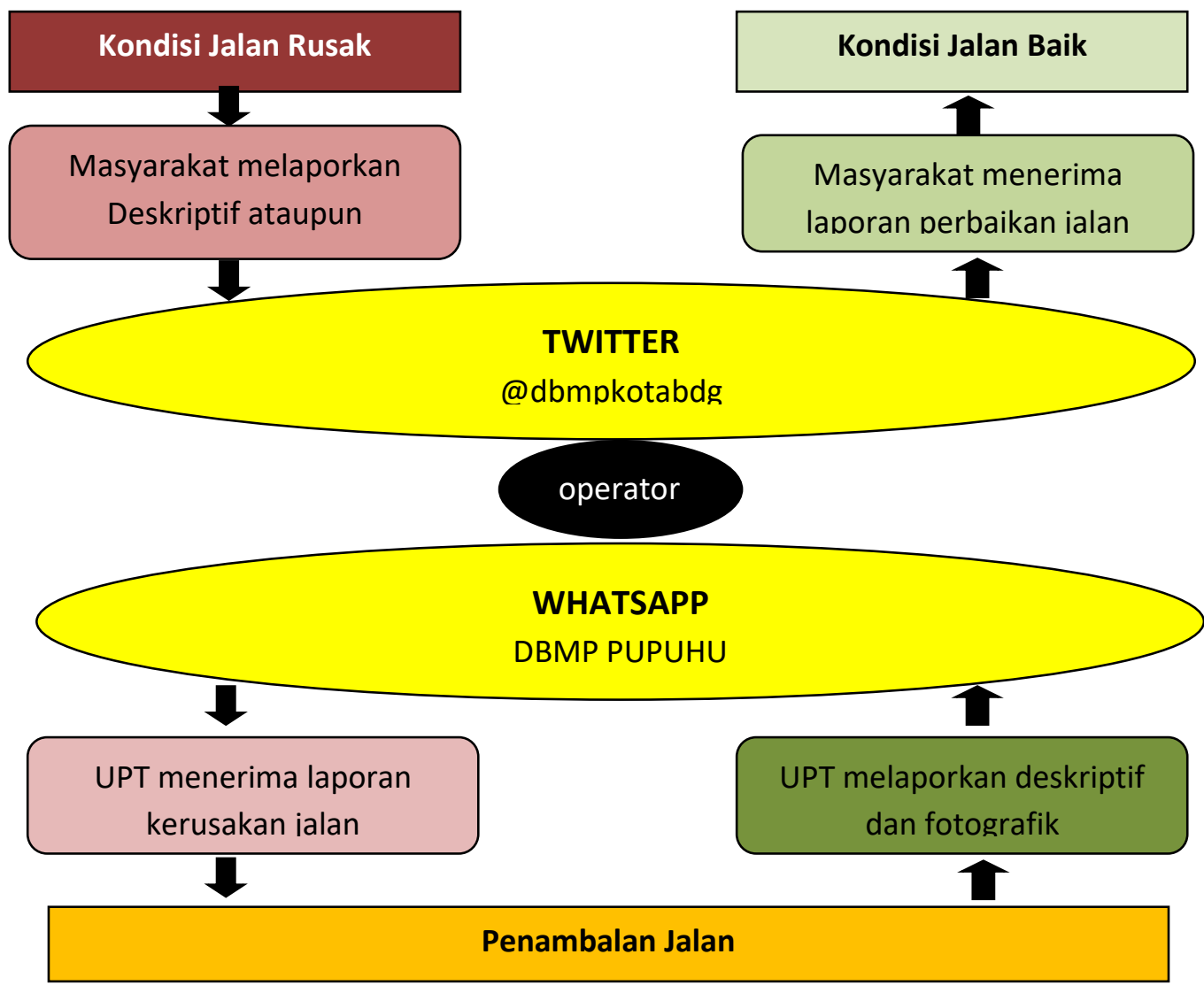

Diagram Alur Perbaikan Jalan

(Sumber : Dinas Bina Marga dan Pengairan Diagram Alur Perbaikan

${ }^{11}$ Hasil wawancara peneliti dengan Staff/Admin twitter DBMP, tanggal 16 Juni 2015 
Walaupun Pemerintah Kota Bandung sudah melakukan koordinasi dengan masyarakat, tetapi menurut Kepala UPT operasional pemeliharaan jalan Bapak Sony Haryadi bahwa masyarakat dalam hal ini masih banyak salah persepsi tentang komposisi jalan yang ada di Kota Bandung. Pemeliharaan ruasruas jalan sepenuhnya bukan wewenang Pemerintah Kota Bandung, akan tetapi terdapat Jalan Provinsi dan Jalan Nasional.

Dalam hasil pemaparan diatas bahwa proses koordinasi yang dilakukan oleh Pemerintah Kota Bandung sudah dijalankan sesuai dengan prosedur kegiatan mulai dari pelaporan oleh masyarakat kemudian pengerjaan perbaikan jalan oleh UPT wilayah dan pelaporan kembali kepada masyarakat mengenai jalan yang sudah diperbaiki. Akan tetapi memang dalam pelaksanaannya selalu ada kekurangan, seperti masalah kesalahpahaman masyarakat mengenai kewenangan jalan kota, provinsi, dan nasional serta mengenai penyebaran akun twitter @ dbmpkotabdg. Dalam pelaksanaannya, program URC tambal jalan tidak terlihat di akhir tahun anggaran karena kehabisan stok aspal. Menurut narasumber hal ini terjadi karena permintaan perbaikan jalan dari masyarakat tidak seimbang dengan anggaran yang ada. $^{12}$

\footnotetext{
${ }^{12}$ Hasil wawancara peneliti dengan 6 Kepala UPT Pemeliharaan Jalan, Bulan Mei 2015
}

\section{d. Kontrol Pemerintahan dalam Program Unit Reaksi Cepat Tambal Jalan di Kota Bandung tahun 2015}

$\begin{array}{llr}\text { Mengenai } & \text { proses } & \text { standar } \\ \text { keberhasilan } & \text { dalam } & \text { suatu }\end{array}$ pelaksanaan kegiatan, ketika peneliti menanyakan standar keberhasilan kegiatan manajemen pemerintahan dalam program Unit Reaksi Cepat Tambal Jalan kepada Bapak Herdis Bekti selaku Kepala Bidang Pemeliharaan Jalan, beliau mengatakan bahwa dalam kegiatan ini dianggap berhasil jika penambalan jalan dapat dilaksanakan dengan cepat dan kualitasnya mampu bertahan lama, tercapainya keselamatan warga Kota Bandung sebagai pengguna infrastruktur jalan. $^{13}$

Berikut tabel 2. mengenai data Laporan Tahun Anggaran 2015 Dinas Bina Marga dan Pengairan Kota Bandung pada Bidang Pembangunan dan Pemeliharaan dalam pelaksanaan Program Pemeliharaan Jalan Kota.

\footnotetext{
${ }^{13}$ Hasil wawancara peneliti dengan Kepala Bidang Pemeliharaan Jalan, tanggal 06 Juni 2015
} 
Tabel 2. Rekapitulasi Laporan Hasil Pekerjaan Program Pemeliharaan Jalan dan Non Program pada 6 UPT dan UPT PCA Tahun Anggaran 2015

\begin{tabular}{|c|c|c|c|c|}
\hline \multirow{2}{*}{ No. } & \multirow{2}{*}{ Lokasi } & \multicolumn{3}{|c|}{ Jenis Kegiatan } \\
\cline { 3 - 5 } & & Program * $\mathrm{M}^{2}$ & $\begin{array}{c}\text { Non Program } \\
* \mathrm{M}^{2}\end{array}$ & Keterangan \\
\hline 1 & UPT. OP. Bojonegara & $8,200.00$ & $11,182.00$ & \\
\hline 2 & UPT. OP. Cibeunying & $8,250.00$ & $14,400.00$ & \\
\hline 3 & UPT. OP. Tegallega & $8,738.00$ & $14,525.00$ & \\
\hline 4 & UPT. OP. Karees & $8,200.00$ & $8,450.00$ & \\
\hline 5 & UPT. OP. Ujungberung & $8,150.00$ & $9,550.00$ & \\
\hline 6 & UPT. OP. Gedebage & $8,200.00$ & $10,093.80$ & \\
\hline 7 & UPT-PCA & 388.64 & $17,752.94$ & \\
\hline & Total= & $49,766.64$ & $85,953.74$ & $135,720.38$ \\
\hline
\end{tabular}

Sumber : Dinas Bina Marga dan Pengairan Kota Bandung Tahun Anggaran 2015

Pada tabel 2. terlihat bagaimana realisasi program pemeliharaan yang dilaksanakan oleh Dinas Bina Marga dan Pengairan Kota Bandung pada Bidang Pembangunan dan Pemeliharaan. Sebanyak 85,953.74 $\mathrm{m}^{2}$ yang merupakan Program Unit Reaksi Cepat Tambal Jalan/Non Program telah dikerjakan pada tahun 2015. Hal ini menunjukan bahwa program tersebut telah terlaksana sebagai upaya untuk memelihara kondisi jalan di Kota Bandung.

Pemerintah Kota Bandung dalam melakukan pengawasan terhadap pelaksanaan program Unit Reaksi Cepat Tambal Jalan dilakukan oleh Kepala Dinas Bina
Marga dan Pengairan Kota Bandung selaku pimpinan SKPD. Selain itu melalui twitter@dbmpkotabdg, Walikota Ridwan Kamil selaku pimpinan beserta masyarakat Kota Bandung dapat mengawasi secara langsung pelaksanaan program Unit Reaksi Cepat Tambal Jalan mengenai laporan-laporan yang diadukan oleh masyarakat dan respon oleh Dinas Bina Marga dan Pengairan Kota Bandung serta pergerakan tim URC dalam melaksanakan kegiatan pemeliharaan jalan akan muncul dalam media sosial tersebut. Seperti yang diutarakan oleh Bapak Eka "Pengawasan dalam program pemeliharaan jalan diawasi oleh 
seluruh stakeholders, karena SKPD terkait telah melakukan transparansi informasi melalui aku twitter DBMP". ${ }^{14}$

Prosedur pengawasan dalam program Unit Reaksi Cepat Tambal Jalan ini dilakukan secara formal dan informal. Secara formal para Kepala UPT yang terlibat dalam anggota tim melakukan pengawasan terhadap pelaksanaan kegiatan oleh unit UPTnya masing-masing. Kemudian mereka melaporkan secara berkala kepada Kepala Bidang Pemeliharaan Jalan selaku koordinator program Unit Reaksi Cepat Tambal Jalan. ${ }^{15}$

Koordinator program Unit Reaksi Cepat Tambal Jalan ini bertugas untuk menghimpun dan melaporkan keseluruhan pelaksanaan pemeliharaan jalan oleh Unit Pelaksana Teknis (UPT) di 6 wilayah Kota Bandung.

Jadi pengawasan yang dilakukan oleh Kepala Dinas Bina Marga dan Pengairan Kota Bandung selaku pemantau program Unit Reaksi Cepat Tambal Jalan berdasarkan pada laporan yang diberikan oleh Kepala Bidang Pemeliharaan Jalan atas rekapitulasi laporan hasil pekerjaan bulanan seluruh Unit Pelaksana Teknis Pemeliharaan Jalan di Kota Bandung Berdasarkan temuan peneliti di lapangan, laporan rutin yang diberikan oleh Koordinator Bidang Pemeliharaan Jalan kepada Kepala

\footnotetext{
${ }^{14}$ Hasil wawancara peneliti dengan Staff/Admin twitter DBMP, tanggal 16 Juni 2015

${ }^{15}$ Ibid
}

Dinas Bina Marga dan Pengairan adalah per tahun. Sedangkan laporan rutin yang dibuat oleh masing masing UPT dibuat per bulan sekali karena tim program Unit Reaksi Cepat Tambal Jalan secara rutin melakukan pemeliharaan jalan.

Selain itu pengawasan juga dilakukan secara informal melalui media sosial whatsapp DBMP PUPUHU, karena pusat koordinasi seluruh tim Unit Reaksi Cepat Tambal Jalan berada di media sosial ini sehingga proses pengawasan dapat dijalankan dengan baik. ${ }^{16}$

Berdasarkan hasil pengawasan yang dilakukan oleh Pemerintah Kota Bandung terhadap pelaksanaan Program Unit Reaksi Cepat Tambal Jalan pada tahun 2015 sebagai upaya pemeliharaan jalan di Kota Bandung, ada kegiatan-kegiatan yang telah dilaksanakan berdasarkan perencanaan yang telah ditetapkan. Namun, ada pula kegiatan-kegiatan yang belum sesuai dengan perencanaan awal, sehingga diperlukan tindakan perbaikan atau korektif dari Pemerintah Kota Bandung.

Berdasarkan hasil evaluasi dan pengawasan yang dilakukan oleh Pemerintah Kota Bandung, pada pelaksanaan program Unit Reaksi Cepat tahun 2015, ada beberapa perencanaan yang telah dilaksanakan berdasarkan target yang ditentukan pada tahun 2015.

Pada tahun 2015, tim Unit Reaksi Cepat Tambal Jalan telah

${ }^{16}$ Ibid 
melaksanakan penambalan jalan berlubang dan pemanfaatan media sosial dengan membentuk akun twitter untuk memfasilitasi laporan dan aspirasi masyarakat. Bentuk pemeliharaan jalan dengan melibatkan partisipasi masyarakat sebagai upaya membangun kesadaran masyarakat agar lebih peduli dalam mewujudkan Kota Bandung sebagai Kota yang nyaman, dilakukan melalui kegiatan yang telah dilaksanakan pada tahun 2015 yaitu :

1. Membentuk Tim URC dengan memfasilitasi keperluan peralatannya

2. Pemanfaatan Media sosial twitter dan whaatsapp sebagai sarana komunikasi dan koordinasi antar tim URC dan masyarakat

3. Pelaksanaan Program URC Tambal Jalan ${ }^{17}$

Hasil dari kegiatan-kegiatan yang dilaksanakan pada tahun 2015 tersebut,

berdasarkan wawancara yang peneliti lakukan dengan Bapak Iskandar Kepala DBMP, Pemerintah Kota Bandung sendiri mengakui bahwa sasaran yang diharapkan dari kegiatan tersebut belum tercapai karena masih ada 2 periode lagi yakni tahun 2015 dan 2016 berdasarkan perencanaan yang ada di RPJMD bahwa Jalan Mulus harus tercapai dalam kurun waktu 3 tahun. Namun, meskipun demikian melalui kegiatan-kegiatan yang dlakukan

${ }^{17}$ Ibid tersebut telah ada pergeseran perilaku dari masyarakat untuk lebih peduli terhadap Kota Bandung dan melakukan pengawasan terhadap Program Unit Reaksi Cepat Tambal Jalan di Kota Bandung. ${ }^{18}$

Pergeseran perilaku tercermin dari data yang peneliti peroleh dari hasil wawancara dengan Bapak Eka selaku staff admin pemegang akun twitter@dbmpkotabdg, bahwa saat ini semua pelaporan masyarakat telah direspon oleh Tim URC Tambal Jalan dengan baik dan mendapatkan sambutan serta apresiasi positif dari masyarakat, bahkan menjadi favorit masyarakat Kota Bandung.

Namun meski demikian Pemerintah Kota Bandung sendiri menyadari atas hasil pengawasan dan evaluasi yang mereka lakukan bahwa sasaran yang dicapai dalam program URC tambal jalan ini masih belum maksimal. Karena berdasarkan perencanannya dalam mewujudkan infrastruktur jalan yang mulus dibutuhkan waktu 3 tahun.

Selanjutnya, hasil pengawasan yang dilakukan oleh Pemerintah Kota Bandung terhadap pelaksanaan program Unit Reaksi Cepat Tambal Jalan pada tahun 2015 menurut Kepala Bidang Pemeliharaan Jalan mengatakan bahwa terdapat laporan dari masyarakat mengenai jalan yang sudah diperbaiki oleh tim Unit Reaksi Cepat Tambal Jalan telah rusak kembali atau tidak bertahan lama. Hal tersebut terjadi karena tim

${ }^{18}$ Hasil wawancara peneliti dengan Kepala DBMP Kota Bandung, tanggal 04 Juni 2015 
URC tambal jalan sering menemui hambatan saat pelaksanaan di lapangan. ${ }^{19}$

Selain itu dalam

pelaksanaannya, menurut para

Kepala UPT pemeliharaan jalan mengatakan bahwa program Unit Reaksi Cepat Tambal Jalan sempat terhenti di akhir tahun anggaran 2015 karena kehabisan stok aspal sehingga semua kegiatan penambalan jalan menjadi tertunda dan dilaksanakan di awal tahun anggaran 2015, hal tersebut terjadi karena anggaran yang tersedia tidak sesuai dengan kebutuhan di lapangan. ${ }^{20}$

Dari penjelasan diatas, karena adanya penyimpangan yang tidak sesuai dengan perencanaan dalam pelaksanaan program Unit Reaksi Cepat Tambal Jalan, menurut Kepala Bidang Pemeliharaan Jalan maka tindakan korektif yang dilakukan oleh Pemerintah Kota Bandung yaitu dengan melanjutkan program yang belum selesai tersebut di tahun berikutnya dengan cara menambah anggaran pengadaan bahan material untuk perbaikan jalan dan anggaran swakelola untuk penambahan tim URC di setiap UPT pemeliharaan jalan.

Selanjutnya tindakan korektif atas hambatan yang terjadi di lapangan, yakni penambalan jalan yang kualitasnya tidak tahan lama sampai saat ini Kepala Bidang

\footnotetext{
${ }^{19}$ Hasil wawancara peneliti dengan Kepala Bidang Pemeliharaan Jalan, tanggal 06 Juni 2015

${ }^{20}$ Hasil wawancara peneliti dengan 6 Kepala UPT Pemeliharaan Jalan, Bulan Mei 2015
}

Pemeliharaan Jalan beserta para Kepala UPT masih beranggapan bahwa perbaikan jalan yang dilakukan tim URC sudah benar akan tetapi hal itu tetap tergantung pada faktor kondisi jalanan tersebut ketika menahan beban kendaraan yang melintas. Maka untuk menangani masalah tersebut Dinas Bina Marga dan Pengairan Kota Bandung memiliki alternatif kebijakan dengan merencanakannya ke dalam program pemeliharaan jalan terprogram atau program peningkatan jalan.

\section{SIMPULAN REKOMENDASI Simpulan}

Berdasarkan hasil penelitian dan pembahasan yang telah tertuang pada bab sebelumnya, maka simpulan terkait dengan Judul Penelitian mengenai Manajemen Pemerintahan dalam Program Unit Reaksi Cepat Tambal Jalan di Kota Bandung Tahun 2015 (Studi pada Dinas Bina Marga dan Pengairan Kota Bandung) ialah sebagai berikut:

Dalam proses perencanaan pemerintahan telah memuat tujuan dari program yang telah dilakukan yakni mempertahankan kinerja jalan tetap dalam kondisi baik, meminimalisirkan kecelakaan yang diakibatkan oleh kerusakan jalan, serta menunjang pertumbuhan ekonomi perkotaan.

Dalam

proses pengorganisasian sumber-sumber pemerintahan, bahwa anggota tim Unit Reaksi Cepat direkrut secara swakelola dan jumlahnya belum 
mencukupi serta SDA dan SDB yang dimiliki adalah berasal dari APBD Kota Bandung dan Bantuan Provinsi tahun 2014.

Dalam proses penggunaan sumber-sumber pemerintahan dalam program Unit Reaksi Cepat Tambal Jalan di Kota Bandung sudah berjalan mulai dari motivasi, arahan, kepemimpinan, komunikasi pemerintahan dan koordinasi. Namun dalam hal komunikasi dan koordinasi antara pemerintah dengan pihak masyarakat belum berjalan dengan baik serta terdapat kendala-kendala yang disebabkan oleh kurangnya ketersediaan bahan material sebagai faktor penggerak pelaksanaan pemeliharaan jalan.

Dalam proses kontrol pemerintahan, proses pengawasan yang dilakukan oleh Dinas Bina Marga dan Pengairan Kota Bandung sudah berjalan optimal, meski terdapat berbagai permasalahan akan tetapi Pemkot Bandung sudah menyiapkan tindakan yang akan dilakukan untuk menangani masalah tersebut.

\section{Rekomendasi}

Dalam proses perencanaan pemerintahan, menurut peneliti sebaiknya pada masa yang akan datang Pemerintah Kota Bandung bisa lebih cepat dalam mengeluarkan dasar aturan terhadap suatu program. Karena suatu program muncul atas adanya permasalahan yang terjadi, sehingga setiap permasalahan tersebut membutuhkan penanganan yang cepat pula, dan apabila pelaksanaan program tersebut melibatkan peran masyarakat, sebaiknya Pemerintah Kota Bandung harus menyediakan fasilitas apa yang dibutuhkan dan masyarakat sebagai pengguna harus mengetahui keberadaan fasilitas yang disediakan oleh Pemerintah.

Dalam

proses pengorganisasian sumber-sumber pemerintahan, menurut peneliti agar pelaksanaan pemeliharaan jalan maksimal sebaiknya Pemerintah Kota Bandung menambah jumlah tim pelaksana program Unit Reaksi Cepat Tambal Jalan sesuai apa yang dibutuhkan oleh Unit Pelaksana Teknis Pemeliharaan Jalan di 6 wilayah Kota Bandung.

Dalam proses penggunaan sumber-sumber pemerintahan, menurut peneliti sebaiknya Pemerintah Kota Bandung membangun komunikasi dan koordinasi yang baik dengan masyarakat terkait informasi yang pemerintah dan masyarakat butuhkan. Dengan begitu maka tidak akan terjadi kesalahpahaman dalam pelaksanaan program tersebut. Selain itu untuk masa yang akan datang, pemerintah Kota Bandung harus menambah anggaran untuk pengadaan bahan material karena program Unit Reaksi Cepat Tambal Jalan harus terus merespon laporan dari warga Kota Bandung sehingga keberadaan Unit Reaksi Cepat harus selalu siap.

Dalam proses pengawasan pemerintahan, menurut peneliti Dinas Bina Marga dan Pengairan 
sudah melakukan proses pengawasan dengan baik, meskipun dalam evaluasi pelaksanaan program Unit Reaksi Cepat Tambal Jalan mengalami hambatan, Dinas Bina Marga dan Pengairan memiliki alternatif kebijakan untuk mengatasi masalah tersebut. Diharapkan untuk masa yang akan datang, pemerintah Kota Bandung lebih mempersiapkan apa yang dibutuhkan di lapangan dengan memperhatikan masalah yang sudah terjadi.

\section{DAFTAR PUSTAKA}

Ahmadi, Rulam, 2014. Metodologi Penelitian Kualitatif, Yogyakarta: Ar-Ruz Media.

Hanafi, Mamduh M, 2011. Manajemen, Yogyakarta : Sekolah Tinggi Ilmu Manajemen YKPN.

Istianto, Bambang, 2011. Manajemen

Pemerintahan (Dalam

Perspektif Pelayanan Publik),

Jakarta : Mitra Wacana

Media.

Ndraha, Taliziduhu, 2011. Kybernology (Ilmu

Pemerintahan Baru) 1, Jakarta: Rineka Cipta.

Sadyohutomo, Mulyono, 2008.

Manajemen Kota dan

Wilayah, Realita dan

Tantangan, Jakarta: PT.

Bumi Aksara.

Salam, Dharma Setyawan, 2007. Manajemen Pemerintahan Indonesia, Jakarta: Djambatan.
Sugiyono, 2014. Memahami Penelitian Kualitatif, Bandung: CV Alfabeta.

Terry, George R, 2013. PrinsipPrinsip Manajemen, Bandung: Bumi Aksara.

Dinas Bina Marga dan Pengairan Kota Bandung. 2014. Dokumen UPT Operasional Tahun 2014. Bandung: Sekretariat Dinas Bina Marga dan Pengairan Kota Bandung. 2014. Laporan Akuntabilitas Kinerja Instansi Pemerintah (LAKIP) Dinas Bina Marga dan Pengairan Kota Bandung. Bandung: Sekretariat Dinas Bina Marga dan Pengairan Kota Bandung. 2014. Rencana Strategis Dinas Bina Marga dan Pengairan Kota Bandung 2013-2018. Bandung: Sekretariat Dinas Bina Marga dan Pengairan Kota Bandung. 2015. Tupoksi Dinas Bina Marga dan Pengairan Kota Bandung. Bandung: Sekretariat Dinas Bina Marga dan Pengairan Kota Bandung. Pemerintah Kota Bandung. 2010. Peraturan Walikota Bandung No. 413 Tahun 2010 tentang Pembentukan dan Susunan Organisasi Unit Pelaksana Teknis pada Lembaga Teknis Daerah dan Dinas Daerah di Lingkungan Pemerintah Kota Bandung. Bandung: Sekretariat Daerah. 2014. Peraturan Daerah Kota Bandung No. 03 Tahun 2014 
tentang Rencana
Pembangunan

Menengah Daerah (RPJMD)

2013-2018. Bandung:

Sekretariat Daerah.

2014. Rencana Pembangunan

Jangka Menengah Daerah (RPJMD) 2014-2018.

Bandung: Sekretariat Daerah.

Republik Indonesia. 2004. UndangUndang Nomor 38 Tahun 2004 Tentang Jalan. Jakarta : Sekretariat Negara.

Republik Indonesia. 2014. UndangUndang Nomor 23 Tahun 2014 Tentang Pemerintahan Daerah. Jakarta : Sekretariat Negara. 